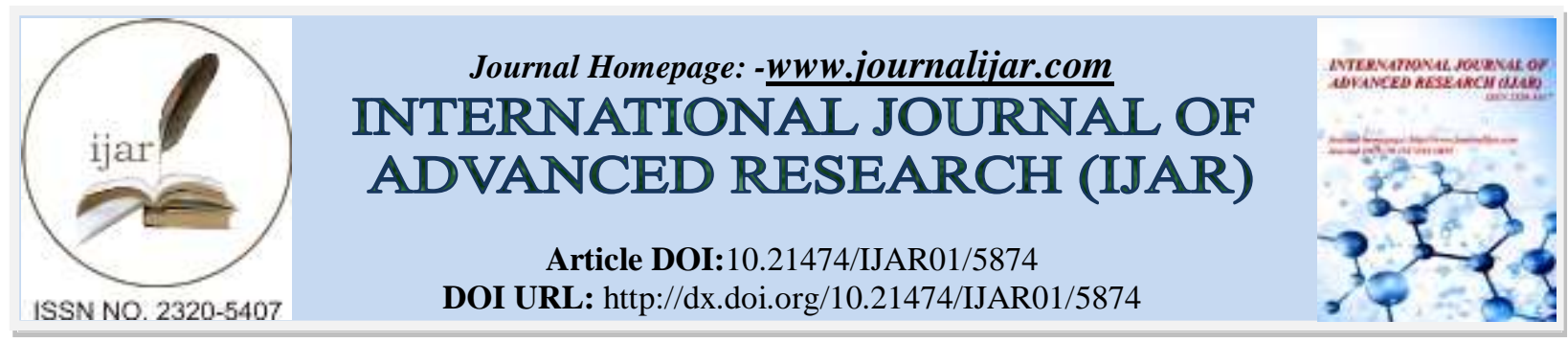

RESEARCH ARTICLE

\title{
CYTOGENETIC STUDIES OF COUPLES WITH IDIOPATHIC INFERTILITY.
}

\author{
Anu $\mathbf{P}^{1}$, Reshmi $V^{2}$, Sanuj C Breezevilla ${ }^{3}$ and Dinesh Roy $D^{4}$. \\ 1. Department of Zoology, SreeNarayana College, Cherthala- 688582, Kerala. \\ 2. Assistant Professor, Department of Zoology, SreeNarayana College, Cherthala- 688582, Kerala. \\ 3. HOD, Assistant professor, Department of Zoology, SreeNarayana College, Cherthala- 688582, Kerala. \\ 4. Genetika, Centre for Advanced Genetic Studies, Pettah P O, Thiruvananthapuram - 695024, Kerala.
}

\section{Manuscript Info}

\section{Manuscript History}

Received: 15 September 2017

Final Accepted: 17 October 2017

Published: November 2017

Key words:-

Cytogenetics, Karyotype and Idiopathic infertility.

\begin{abstract}
Infertility is a global health issue affecting approximately $8-10 \%$ of couples. $30 \%$ of infertile couples are diagnosed with unexplained or idiopathic infertility. Idiopathic infertility is defined as the lack of an obvious cause for a couple's infertility. It can cause emotional stress and a range of psychological reactions including depression and anxiety. This review discusses the cytogenetic studies of couples with idiopathic infertility. The present study includes 28 infertile couples and 16 healthy control couples. All these subjects were karyotyped based on their characteristics. The cytogenetic analysis was correlated with risk factors of subjects. Subjects with abnormal karypotype along with various risk factors may leads to infertility. The principal treatments for unexplained infertility include expectant observation with timed intercourse and lifestyle changes. Medication along with lifestyle modification will help to reduce the risk for infertility.
\end{abstract}

Copy Right, IJAR, 2017,. All rights reserved.

\section{Introduction:-}

The World Health Organization (WHO) estimates that 8-12\% of couples around the world experience difficulty in conceiving (World Health Organization, 1991). Infertility is major life crisis for many couples (Leiblum and Greenfield, 1997). Unexplained infertility refers to the absence of a definable cause for a couple's failure to achieve pregnancy (Practice Committee of American Society for Reproductive Medicine, 2008). Unexplained infertility is a term that has been applied to as many as 30-40\% of infertile couples (Smith et al., 2003). The potential causes of unexplained infertility have been described as disturbance in endocrinological balance, immunology, genetic and reproductive physiology (Pellicer et al., 1998). The proportion of couples suffering from unexplained infertility is popularly quoted as $16 \%$ but the range varies from $0 \%$ to $37 \%$. The prevalence of unexplained infertility is still truly debatable because the diagnosis of unexplained infertility is due to lack of a specific test or may be due to misdiagnosis.

Male and female factors each account for approximately $35 \%$ in cause of infertility. $10 \%$ infertility is unexplained. In unexplained infertility, the actual cause for infertility cannot be detected; perhaps there is dysfunctional interaction between the sperm and the oocyte, poor quality of the embryo, or a disruption at the implantation site. Other possible reasons behind unexplained infertility are endometriosis and pelvic adhesion (Sabarre et al., 2013). 
Untreated sexually transmitted infections (STIs) are among the factors that cause damage to the reproductive system of men and women. Chlamydia and gonorrhea are most common STI which lead to infertility (Goundry, Finlay and Liewellyn, 2013).

Testicular infertility is a disorder at the level of sertoli or/and Leydig cells and is the major cause of male infertility. Varicoceles is a detrimental effect on sperm count, motility or morphology. Alcohol abuse in men has been reported to cause impaired testosterone production, and atrophy of testes, which can result in impotence, infertility and reduced male secondary sexual characteristics (Guzick et al., 2004).

Significant advances have occurred in the diagnosis and more importantly in the treatment of reproductive disorders over the past decade. The overall incidence of infertility has remained stable; however, the success rates have markedly improved with the widespread use of assisted reproductive technologies. Changes in genetic factors contribute to the etiology of infertility in humans. Defects in reproductive health of a human will cause future health problems. Hence the present study was undertaken to evaluate cytogenetic studies on couples with idiopathic infertility.

\section{Material and Methods:-}

Twenty eight couples suffering with infertility were selected as study subjects and 16 healthy couples were also selected as control for this study. Detailed demographic, clinical and lifestyle characteristics were recorded using proforma. These couples were referred from various infertility centers of Kerala to Genetika, Centre for Advanced Genetic Studies, Trivandrum, Kerala.

The fresh blood was collected by venipuncture and transferred into sodium heparin vacutainer. Added 5 to 6 drops of whole blood samples to a vial containing $10 \mathrm{ml}$ of RPMI 1640 medium supplemented with $15 \%$ foetal bovine serum. Then phytohaemagglutinin (PHA, $10 \mu \mathrm{g} / \mathrm{ml}$ ) was added to proliferate the lymphocyte cells and incubated at $37^{\circ} \mathrm{C}$ for $72 \mathrm{hrs}$. At the 70 th hour, to the culture added a drop of colchicine $(0.04 \mu \mathrm{g} / \mathrm{ml})$ to arrest the cell division at metaphase, then mixed gently and kept in incubator at $37^{\circ} \mathrm{C}$ for 2 hours. After incubation they were treated with a hypotonic $\mathrm{KCl}$ solution $(0.075 \mathrm{M})$ for $20 \mathrm{~min}$ and fixed in fresh fixative solution (methanol: acetic acid, 3:1). The cells were dropped onto slides and the slides were air dried and stained with $10 \%$ Giemsa. Washed the slides and observed under a research microscope through 100x objective. For karyotyping and detecting the structural anomalies, GTG banding technique was performed. To detect numerical and structural abnormalities 20-25 metaphases were analyzed and 5-6 metaphases were karyotyped.

\section{Observations and Results:-}

In the present study, demographic and physiological characteristics of study subjects were compared with control subjects. The age of study subjects ranged from 20 to 50 years with a mean age of 36.1 years and the age of control subjects ranged from 30 to 41 years with a mean age of 36.3 years. Among 28 study subjects, $71.42 \%$ belonged to rural area followed by urban area $(14.2 \%)$ and coastal area $(3.5 \%)$.

Table 1:- Comparison of Karyotype according to subjects.

\begin{tabular}{|l|l|l|l|}
\hline Subjects & Number of couples & Normal karyotype & Abnormal karyotype \\
\hline Study subjects & 28 & 24 & 4 \\
\hline Control subjects & 16 & 16 & 0 \\
\hline
\end{tabular}

Out of 28 couples studied, 4 couples were showed abnormal chromosome pattern and remaining couples having normal chromosome pattern. All the couples in the control subjects were showed normal karyotype.

Table 2:-Distribution of karyotype according to demographic and clinical characteristics of subjects.

\begin{tabular}{|l|l|l|l|l|l|l|l|}
\hline Category & $\begin{array}{l}\text { Variabl } \\
\text { es }\end{array}$ & $\begin{array}{l}\text { Number } \\
\text { of males }\end{array}$ & $\begin{array}{l}\text { Normal } \\
\text { male } \\
\text { karyotype }\end{array}$ & $\begin{array}{l}\text { Abnormal } \\
\text { male } \\
\text { karyotype }\end{array}$ & $\begin{array}{l}\text { Number } \\
\text { of } \\
\text { females }\end{array}$ & $\begin{array}{l}\text { Normal } \\
\text { female } \\
\text { karyotype }\end{array}$ & $\begin{array}{l}\text { Abnormal } \\
\text { female } \\
\text { karyotype }\end{array}$ \\
\hline Age (Years) & $<30$ & 3 & $2(66.67 \%)$ & $1(33.3 \%)$ & 13 & $12(92.3 \%)$ & $1(7.7 \%)$ \\
\cline { 2 - 8 } & $\begin{array}{l}30 \text { to } \\
40\end{array}$ & 18 & $17(94.4 \%)$ & $1(5.6 \%)$ & 13 & $11(84.62 \%)$ & $2(15.38 \%)$ \\
\cline { 2 - 8 } & $\geq 40$ & 7 & $5(71.42 \%)$ & $2(28.58 \%)$ & 2 & $1(50 \%)$ & $1(50 \%)$ \\
\hline Birth order & $<3$ & 13 & $11(84.7 \%)$ & $2(15.3 \%)$ & 14 & $12(85.8 \%)$ & $2(14.2 \%)$ \\
\hline
\end{tabular}




\begin{tabular}{|c|c|c|c|c|c|c|c|}
\hline & $\geq 3$ & 15 & $13(86.7 \%)$ & $2(13.3 \%)$ & 14 & $12(85.7 \%)$ & $2(14.3 \%)$ \\
\hline \multirow[t]{2}{*}{ Occupation } & $\begin{array}{l}\text { Sedent } \\
\text { ary }\end{array}$ & 24 & $22(91.6 \%)$ & $2(8.3 \%)$ & 7 & $5(71.4 \%)$ & $2(28.5 \%)$ \\
\hline & $\begin{array}{l}\text { Non } \\
\text { sedenta } \\
\text { ry }\end{array}$ & 4 & $2(50 \%)$ & $2(50 \%)$ & 21 & $19(90.4 \%)$ & $2(9.5 \%)$ \\
\hline \multirow{2}{*}{$\begin{array}{l}\text { Family H/o } \\
\text { infertility }\end{array}$} & Yes & 2 & 0 & $2(100 \%)$ & 1 & 0 & $1(100 \%)$ \\
\hline & No & 26 & $24(92.3 \%)$ & $2(7.7 \%)$ & 27 & $24(88.9 \%)$ & $3(11.1 \%)$ \\
\hline \multirow{2}{*}{$\begin{array}{l}\text { History of } \\
\text { diabetes }\end{array}$} & Yes & 8 & $5(62.5 \%)$ & $3(37.5 \%)$ & 3 & $1(33.3 \%)$ & $2(66.7 \%)$ \\
\hline & No & 20 & $3(95 \%)$ & $1(5 \%)$ & 17 & $16(94 \%)$ & $1(5.9 \%)$ \\
\hline \multirow{2}{*}{$\begin{array}{l}\text { History of } \\
\text { hypertension }\end{array}$} & Yes & 5 & $4(80 \%)$ & $1(20 \%)$ & 3 & $2(66.6 \%)$ & $1(33.3 \%)$ \\
\hline & No & 23 & $20(86.9 \%)$ & $3(13 \%)$ & 25 & $22(88 \%)$ & $3(12 \%)$ \\
\hline \multirow{2}{*}{$\begin{array}{l}\text { History of } \\
\text { Dyslipidemia }\end{array}$} & Yes & 11 & $11(100 \%)$ & 0 & 4 & $2(50 \%)$ & $2(50 \%)$ \\
\hline & No & 17 & $13(76.4 \%)$ & $4(23.5 \%)$ & 24 & $22(91.6 \%)$ & $2(8.3 \%)$ \\
\hline \multirow{2}{*}{$\begin{array}{l}\text { H/o Parental } \\
\text { consanguinity }\end{array}$} & Yes & 3 & $2(66.6 \%)$ & $1(33.3 \%)$ & 1 & 0 & $1(100 \%)$ \\
\hline & No & 25 & $22(88 \%)$ & $3(12 \%)$ & 27 & $23(85.1 \%)$ & $4(14.8 \%)$ \\
\hline
\end{tabular}

Table 2 represents the demographic and clinical characters of subjects. Age of subjects were grouped into <30, 30 to 40 and $\geq 40$ years. Subjects with advanced age ( $\geq 40$ years) were showed 2 abnormal male and 1 abnormal female karyotype. Subjects having family H/o infertility were showed higher number of abnormal karyotype. 3 male and 2 female subjects with H/o diabetes were showed abnormal karyotype. Among the subjects two Hypertensive subjects showed abnormal karyotype. 4 couples having parental consanguinity and 2 of them have abnormal karyotype.

Table 3:- Distribution of Karyotype according to demographic characteristics of couples

\begin{tabular}{|l|l|l|l|l|}
\hline Category & Variables & Number & Normal karyotype & Abnormal karyotype \\
\hline \multirow{4}{*}{ Religion } & Hindu & 15 & $13(86.7 \%)$ & $2(13.3 \%)$ \\
\cline { 2 - 5 } & Muslim & 7 & $3(42.9 \%)$ & $4(57.1 \%)$ \\
\cline { 2 - 5 } & Christian & 6 & $4(66.7 \%)$ & $2(33.3 \%)$ \\
\hline \multirow{5}{*}{ Residence } & Rural & 20 & $17(85 \%)$ & $3(15 \%)$ \\
\cline { 2 - 5 } & Urban & 7 & $6(85.8 \%)$ & $1(14.2 \%)$ \\
\cline { 2 - 5 } & Coastal & 1 & $1(100 \%)$ & 0 \\
\hline \multirow{5}{*}{ Duration of married life (years) } & $<5$ & 12 & $9(75 \%)$ & $3(25 \%)$ \\
\cline { 2 - 5 } & 5 to 10 & 14 & $11(78.5 \%)$ & $3(21.4 \%)$ \\
\cline { 2 - 5 } & $>10$ & 2 & 0 & $2(100 \%)$ \\
\hline \multirow{3}{*}{ Economic status } & High & 5 & $3(60 \%)$ & $2(40 \%)$ \\
\cline { 2 - 5 } & Medium & 19 & $13(68.4 \%)$ & $6(31.5 \%)$ \\
\cline { 2 - 5 } & Low & 4 & $4(100 \%)$ & 0 \\
\hline
\end{tabular}

In table 3, majority of the couples was Hindu, of these 2 of them having abnormal karyotype. Highest number of abnormal karyotype was showed by Muslim couples. Subjects having increased duration of married life (>10 years) were showed abnormal karyotype.

Table 4:-Distribution of Karyotype according topPhysiological characteistics of subjects

\begin{tabular}{|c|c|c|c|c|}
\hline Category & Variables & Number & Normal karyotype & Abnormal karyotype \\
\hline \multirow[t]{2}{*}{ Age at Menarche (Years) } & $<15$ & 25 & $23(92 \%)$ & $2(8 \%)$ \\
\hline & $\geq 15$ & 3 & $1(33.3 \%)$ & $2(66.6 \%)$ \\
\hline \multirow[t]{2}{*}{ Menstrual periods } & Regular & 20 & $19(95 \%)$ & $1(5 \%)$ \\
\hline & Irregular & 8 & $5(62.5 \%)$ & $3(37.5 \%)$ \\
\hline \multirow[t]{2}{*}{ Endometriosis } & Yes & 2 & $1(50 \%)$ & $1(50 \%)$ \\
\hline & No & 26 & $23(88.4 \%)$ & $3(11.5 \%)$ \\
\hline \multirow[t]{2}{*}{ Usage of contraceptive drugs } & Yes & 1 & 0 & $1(100 \%)$ \\
\hline & No & 27 & $23(85.1 \%)$ & $4(14.8 \%)$ \\
\hline \multirow[t]{2}{*}{ PCOS } & Yes & 3 & 0 & $3(100 \%)$ \\
\hline & No & 25 & $21(84 \%)$ & $4(16 \%)$ \\
\hline \multirow[t]{2}{*}{ Semen analysis } & Normal & 23 & $23(100 \%)$ & 0 \\
\hline & Azoospermia & 2 & 0 & $2(100 \%)$ \\
\hline
\end{tabular}




\begin{tabular}{|l|l|l|l|}
\hline Oligospermia & 1 & 0 & $1(100 \%)$ \\
\hline Not known & 2 & $1(50 \%)$ & $1(50 \%)$ \\
\hline
\end{tabular}

Physiological characters of the subjects were given in table 4. Female subjects were showed their age at menarche into $<15$ and $\geq 15$ years. Subjects with menarche $\geq 15$ years were showed abnormal karyotype. 3 subjects with irregular menstruation showed abnormal karyotype. 2 subjects with endometriosis, 1of them were showed normal and other one showed abnormal karyotype. Subjects having PCOS were showed abnormal chromosome pattern. In male subjects, 23 were normal, 2 were azoospemic and 1 was oligospermic. Subjects having azoospermia and oligospermia were showed abnormality in their chromosome pattern.

\section{Discussion:-}

The incidence of infertility and sterility increases as the age of the female partner increases (Shenfield et al., 1993). In present study, advancing age of subjects showing increased number of abnormal karyotype. According to Broekmans et al., (2004) showed that age is directly proportional to infertility. Baird and Wilcoxtested, (1986) hypothesis, prenatal exposure to cigarette smoke is associated with impaired fertility in adulthood. Ratcliffe et al., (1992) showed no significant effects of early exposure to smoking on semen characteristics, hormone levels (FSH, LH and T), urogenital abnormalities or perceived infertility problems. But the present study showed that smoking reduces the fertility rate and smokers were showing higher number of abnormal karyotype.

Snow et al., (1995) showed the community based study of 17 males, whose female partners had been reported as being infertile, showed that eight males (47\%) had severe semen abnormalities that could have been responsible for the infertility reported in their female partners. Other studies have also shown that azoospermia was present in 6.6\% of males attending a general infertility clinic and $35 \%$ in those attending male infertility clinics. The current study also showed significant relationship between semen quality and infertility. According to Zlotogora, (2006) in communities with a high level of consanguineous marriage, diagnosis of a recessive disorder in one or more members of the same family is generally indicative of a mutation. In the present study, subjects with parental consanguinity showed highest number of abnormal karyotype.

Mokhtar et al., (2006) revealed that females with the age of menarche more than 15 years were more risky to develop infertility than those with age of menarche less than 15 years. In the present study, the subjects with menarche at $>15$ years were showed high amount of abnormal karyotype.

Boomsma et al., (2006) reported that female infertility is varies worldwide ranging from $3 \%$ to $7 \%$. Polycystic ovarian syndrome is a common condition estimated to affect $4-18 \%$ women in the reproductive age. PCOS is associated with reproductive, psychological, metabolic and cardiovascular diseases. Lifestyle changes, such as losing weight, can trigger body changes that facilitate conception in women with PCOS. In the present study showed that subjects with PCOS have abnormality in their chromosomal pattern.

\section{Conclusion:-}

The findings from the present study concluded that higher percentage of abnormal karyotype was found in study subjects than control subjects. The higher percentage of abnormal karyotype was found in couples having advancing age, increased duration of married life, family $\mathrm{H} / \mathrm{o}$ infertility and $\mathrm{H} / \mathrm{o}$ parental consanguinity. The risk is more in couples having abnormal karyotype and they are suggested to undergo genetic counseling. So genetic testing is important in all infertile couples especially in idiopathic case. The treatment for unexplained infertility is therefore, by definition, empiric because it does not address aspecific defect or functional impairment. The principal treatments for unexplained infertility include expectant observation with timed intercourse and lifestyle changes. 


\section{Reference:-}

1. Baird, D. D., Wilcox, A. J. (1986). Future fertility after prenatal exposure tocigarette smoke. Fertil Contracept;46(3):368-72.

2. Boomsma, C. M., Eijkemans, M.J., Hughes, E.G., Visser, G. H., Fauser, B.C., Macklon, N.S. (2006). A metaanalysis of pregnancy outcomes in women with polycystic ovary syndrome. Hum Reprod Update, 12: 673-83.

3. Broekmans, F. J., Faddy, M. J., Scheffer, G. (2004). Antralfolliclecounts are related to age at natural fertility loss and age at menopause.Menopause;11(6 Pt 1):607-14.

4. Goundry, Ral., Finlay, E. R., Liewellyn, C.D. (2013). Talking about links between sexually transmitted infections and infertility with college and university students from SE England, UK: a qualitative study. Reprod Health. 10(47):1-7. doi:10.1186/1742-4755-10-47.

5. Guzick, D.S., Coutifaris, C., and M yeres, E.R., (2004). Histological dating of timed endometrial biopsy tissue is not related to fertility status. Fertil Sterile; 82 :pp 1264-1268.

6. Leiblum, S. R., and Greenfield, D. A. (1997). The course of infertility: immediate and long term reactions. Leibulm S R (ed) Infertility: psychological issues and counseling strategies, 83-102.

7. Mokhtar, S., Hassan, H.A., Mahdy, N., Elkhwsky, F., Shehata, G. (2006). Risk factors for primary andsecondary female infertility in Alexandria: ahospital-based case-control study. JMRI., 27: 255-261.

8. Pellicer, A., Albert, C., Mercader, A., Bonilla-Musoles, F., Remohi, J., Simon, C. (1998). The follicular and endocrine environment in women with endometriosis; local and systematic cytokineproduction. Fertil.Steril. 70, 425-431.

9. Practice Committee of American Society for Reproductive Medicine, (2008). Definitions of infertility and recurrent pregnancy loss. FertilSteril; 90:S60.

10. Ratcliffe, J. M., Gladen, B. C., Wilcox, A. J., Herbst, A. L. (1992). Does early exposure tomaternal smoking affect future fertility in adult males? Reprod Toxicol;6(4):297-307.

11. Sabarre, K. A., Khan, Z., Whitten, A. N. et al., (2013). A qualitative study of Ottawa university students' awareness, knowledge and perceptions of infertility, infertility risk factors and assisted reproductive technologies (ART). Reprod Health J;10 (41):1-10.

12. Shenfield, F., Doyle, P., Valentine, A. (1993). Effects of age,gravidity and male infertility status on cumulative conception ratesfollowing artificial insemination with cryopreserved donor semen: analysisof 2998 cycles of treatment in one centre over 10 years. Hum Reprod;8:60-4

13. Smith, S., Pfiefer, S.M., Collins, J. (2003). Diagnosis and managementof female infertility.JAMA $290,17$.

14. Snow, R., Okonofua, F., E., Kane, T. et al. (1995). Prevalence of determinants of infertility in Ile-Ife, Nigeria. Contracep, Fert Sex 1995; 23:554.

15. World Health Organization, (1991). Infertility: a tabulation of available data on prevalence of primary and secondary infertility. WHO/MCH/91.9.

16. Zlotogora, J., Hujera,t Y,, Barges, S., Shalev, S.A., Chakravarti, A. (2006). The fate of 12 recessive mutations in a single village. Ann Hum Genet., 202-208. 